DOI https://doi.org/10.18551/rjoas.2018-12.03

\title{
STRATEGY OF IMPROVING HUMAN RESOURCE MANAGEMENT PLANNING IN COMPANY DEVELOPMENT
}

\author{
Sobakh Nurus \\ STKIP PGRI Pasuruan, Indonesia \\ E-mail: zobex.stkippgripas@gmail.com
}

\begin{abstract}
To achieve the better requirements in company, Human resources management planning needs to be identified and planned. The management determines the company of human resources to be placed in the desired position and to obtain systematic improvements. It requires both elements, they are quality and quantity. To achieve high quality Human resources management requires some strategy. This study will investigate the strategy of human empowerment and development methods for the purpose of improving the effectiveness of company. This study uses a qualitative descriptive design. The researcher used a case study to investigate the strategy of human resources management planning development in company. The data used in this research was various sources reference for research writing. Data analysis techniques used was data classification. The obtained data are classified and organized then; the researcher finds the strategy of human resources planning management development. The result of the research shows that individual performance in every activity is the key to achieving productivity. Performance determines where people and other resources in the company are brought together the final results based on the level of quality and standards. It has been set. Consequently, company needs human resources who have expertise and unique abilities based on the vision and mission of the company. Therefore, company must be able to develop the potential of human resources to be more creative and innovative.
\end{abstract}

\section{KEY WORDS}

Management, business, human resources, development.

Some experts put forward several notions of human resource management planning. It is a series of future oriented steps or action and how a resource is allocated with business activities. It will be funded, supported and implemented. Therefore, it can achieve the objectives (Sofo, 2014). Other experts say that human resource planning is a process existing human resources which have been identified, defined and planned for the needs of the company. It aims to meet both short and long term needs (Prashanti, 2013).

Bulla and Scoh (1994) define Human Resource planning is a process to ensure human resource. The requirements in company have been identified and planned to achieve the specified requirements. According to Erick Vetter (in Widajanti, 2007) human resources planning is a process where management determines how the company should move from the current state of human resources to the desired position in the future. It has been seen as a linear process by using short-term data and processes as a long-term planning guide. systematic improvements need to be given to the inputs, processes and test systems to ensure the creation of high quality. Optimal quality of human resouces planning is expected. The achievement of human resources can master the knowledge, skills and expertise in accordance with the evolving science and technology (Sobakh, 2017)

Human resources planning follows the concept that humans are the most important source of strategy in an company. In general, Human resources planning is related to the right resources for long-term and short-term business. It requires both element, they are quality and quantity. Human resources planning relates to a larger issue of human empowerment and development methods for the purpose of improving the effectiveness of an company (Prashanti, 2013). Thuman resourcesough human resources planning, management tries to get the right person, in the right amount, at the right place and at the 
right time, and produces long-term maximum satisfaction for both the company and the individual professional competence, it means human resources should have a broad knowledge of the subject matter that will be taught. The management should have knowledge of theoretical concepts, able to choose the appropriate method and able to use planing in human resources development (Sobakh, 2017).

According to Schuler and Walker (1990) in Widajanti (2007), Human resources planning includes 5 (five) stages, they are (1) Identifying objectives, (2) Forecasting the needs or basic requirements of human resources, (3) Assessing the skills that have been possessed and characteristics other internal offers, (4) Determining the main needs of human resources, and (5) Developing a plan of activity and program activities to ensure the placement of the right people in the right place. Human resources activities are described in the human resources terms, they are:

1. Short-term planning (up to one year) is often referred to as a human resource strategy, it is including:

a. Predicting supply and demand that can be predicted with certainty (what work needs to be filled and offered, how and where to get those people)

b. Setting goals that are easy to quantify (including: attracting, assessing and determining employees needed for various jobs)

c. Design and implementation of short-range programs (for example: employee withdrawal programs, selection programs, performance appraisal systems to identify performance improvements and award compensation, training programs that emphasize developing skills needed in the future, compensation systems designed to achieve short-term goals and are expected to assist the process of achieving a longer term goal

d. Evaluate short-term planning (including: an assessment of how well goals have been achieved). Because short-term goals are generally easily quantified (for example: accommodating the number of job applicants, determining the number of hired employees and the level of employee performance), then a systematic evaluation of human resources programs to meet the short-term needs of the company is quite flexible and some evaluations are in fact can be done by large company.

2. Medium-term planning (period of two or human resources years), it is including:

a. Predicting medium-term demand, in this case strategic planning seeks to predict companyal output, for example: expected production, volume and level of sales,

b. Predict medium-term offer. To predict medium-term supply can be derived from external or internal information sources, but usually internal information is crucial and more feasible,

c. Set goals. The medium-term objective is a series of action plans developed to achieve goals thuman resourcesough joint efforts of human resources planning and relevant managers in an company. Medium-term goals are more visible in terms of: re-adjusting the skills, attitudes and behavior of employees to adjust the main changes needed in the business, such as adjusting human resources practices to changes in employee needs,

d. Design and implementation of medium-term programs that can help employees adjust to companyal changes. These programs include: training or retraining programs (this is influenced by technological changes), services related to work that require new management styles (production of goods, values of service orientation, delivery of goods), good readiness in the long run short to attract new or hired employees who can encourage longer-term programs, economic conditions force downsizing (there are human resources main drivers for medium-term programs, namely: companyal restructuring (including: mergers and acquisitions), reduction in labor which often follows companyal restructuring and adaptation to a diverse workforce).

e. Medium-term evaluation. Because the medium term is more uncertain, contingency and broader scope, the adjustment of the analysis unit is often at the productivity of the department or business unit.

3. Long term (more than thes see years) It is including:

a. Forecasting demand and supply related to succession challenges. While the succession planning program itself is a complex system to protect long-term corporate 
health. The main goal of the succession management program is to develop a strong leadership team for strategic tasks (Leibman et. Al., 1996 in Widajanti, 2004). Key activities in forecasting long-term demand and supply include:

b. Identifying employees who have high potential, identifying what is needed provides learning experiences to develop competencies. While a good development program, includes a variety of components: selection procedures, development plans, mentorship, performance review and career planning activities that involve employees in planning and monitoring their own development.

c. Design and implementation program, this can be done by developing the talents of people who have better mental abilities, which are psychologically suited to what the company needs for innovation and change, planning succession and career development and quality improvement programs,

d. Long-term planning evaluation. Succession program evaluation emphasizes the ability to predict individual outcomes, such as career progress and satisfaction. Long-term evaluation is also applied to evaluate long-term programs that use company results, such as: share price, market share, receipt of industry awards and so on.

\section{METHODS OF RESEARCH}

Based on the problem of the study stated above, the suitable design of this research is qualitative research. This research shows the result of strategy of human resources planning management. These strategy consist of integrated planning for the future company, it involve working desaign, job carier, training, development, management, success, remuneration, retirement in a natural setting. Dörnyei (2007: 40) the qualitative study design is to describe the real phenomena that is occured naturally or the real fact situation is undercontrol in this study. this study attempts to understand how is the strategy to overcome human resource planning management.

Qualitative research engages case study (Johnson and Christensen, 2008:29). This study aims to find the facts of human resource planning problem solving. The data is collected in words. It focused on the strategy of human resource planning management. The data analyzed inductively and explored the meaning of thus, the suitable strategy selected to investigate research question use qualitative research design.

The obtained data from the observation and interview is analyzed inductively. The obtained data are collected into one and classified then, the researcher find the solution of human resources planning strategy. After that the researcher analyze them in line with the research question and decide them what important to be learned. The result of the analysis is drawn a conclusion

Since the data collections in qualitative design. The data presente in word and sentences form. Unstructured interview is used to gain depth data. The researcher classify the data into relevant unit which enable to solve the research objective. The data which does not have relation to the strategy of human resources planning the researcher will reduce them. The researcher analyze them in line with the research question and determine them what significant things to be learned.

\section{RESULTS AND DISSCUSION}

The availability of human resources needed to carry out tasks in the future is very important to ensure that the activities of an company can be carried out properly. The actions to be taken must be planned in advance to ensure and minimize disruption to the plans that have been made in advance. According to Hariandja (2007) good human resources planning will:

1. Improve utilization of human resources;

2. Adjusting human resources activities and needs in the future efficiently;

3. Improve efficiency in attracting new employees; 
4. Completing human resources information that can help the activities of human resources and other company units.

In addition, planning human resources is considered important because it is expected to provide several benefits for both the company and employees. According to Rivai (2004) these benefits include:

1. Companies can better utilize the human resources that exist in the company. Human resource planning also needs to begin with an inventory of human resources that are already in the company. The inventory includes:

a. Number of employees available;

b. Various qualifications;

c. Working period of each employee;

d. Knowledge and skills possessed, both formal education and job training programs that have been followed;

e. Talents that still need to be developed;

f. Employee interests, especially those relating to activities outside of work assignments.

The results of the inventory are very important, not only in order to utilize human resources in carrying out current tasks, but at least relate to four interests in the future, namely:

g. Promotion of certain employees to fill vacancies that are higher if due to various reasons there is a vacancy;

h. Increased ability to carry out the same tasks;

i. In the event of a transfer of work area which means that someone is assigned to a new location but the nature of the job assignment does not change.

2. Human resource sough mature human resource planning, they work effectiveness can also be further enhanced if existing human resources are in accordance with the needs of the company. Standard Operating Procedure (SOP) as a work guideline that has been owned which includes: a conducive work atmosphere, work tools in accordance with the duties of each human resource available, the guarantee of work safety, all systems are running well, can be applied properly company and placement of human resources have been calculated based on needs and workload.

3. Productivity can be further enhanced if you have data about knowledge, work, training that has been followed by human resources. By employing in various educations and training encourage employees to increase their productivity. Human resources through education and training can improve the skills and skills of human resources followed by an increase in work discipline that will produce something more professional in handling work that is directly related to the interests of the company.

4 Human resource planning is related to the determination of future workforce needs, both in terms of the number and qualifications to fill various positions and carry out new activities in the future.

5. One aspect of human resource management which today is perceived more and more important is the pen $\mathrm{n}$ Subscribe employment information. By the availability of fast and accurate information, it is increasingly important for companies, especially companies that have many human resources with branches spread in various places (both domestically and abroad). With this information, it will be easier for management to carry out human resource planning based on advanced technology which is an unavoidable need in an era of rapid change.

6. As understood, one of the preliminary activities in planning including human resource planning is research. Based on the material obtained and the research carried out for the benefit of human resource planning, there will be a proper understanding of the labor market situation in the sense of:

- Demand for labor users for labor is seen in terms of number, type, qualifications and location; 
- Number of job seekers along with areas of expertise, skills, professional background, wage or salary levels and so on. Understanding is important because the form of the plan that is prepared can be adjusted to the situation of the job market.

7. The human resource plan is the basis for the preparation of work programs for the work unit which handles human resources within the company. One aspect of the work program is the procurement of new employees to strengthen the existing workforce in order to improve the company's ability to achieve its goals and objectives. Without human resource planning, it is difficult to develop realistic work programs.

8. Knowing the labor market. The job market is a source for finding potential human resources for recruiting within the company. With the existence of human resource planning data in addition to making it easier to find candidates that match the needs, it can also be used to help other companies that need human resources.

9. Reference in developing human resource development programs. Human resource planning can be used as one of the reference contributions, but can also come from other sources. With complete data about the potential of human resources, it will be easier to develop programs that are more mature and more accountable. Based on these things, can be known the benefits of human resource planning in a company as something very important, for the smooth and the achievement of the objectives of the company.

Concepts and strategy of human resource planning. Before observing further about the importance of human resources planning or human resources planning, it is necessary to explain in advance about the steps of human resources planning. Based on the function to assist the company in achieving its objectives, it can be seen from the perspective of human resources and the focus of attention of human resources planning. It is on the process of forecasting and determination of human resources needs in the future, then the steps of human resources planning according Hariandja (2007) is as follows:

- Analysis of several factors that cause changes in human resources needs;

- Forecasting human resources needs;

- Determination of human resources needs in the future;

- Analysis of human resource availability and capability;

- Determination and implementation of the program.

1. analysis causal change factor

(External, organitation, change of worker)

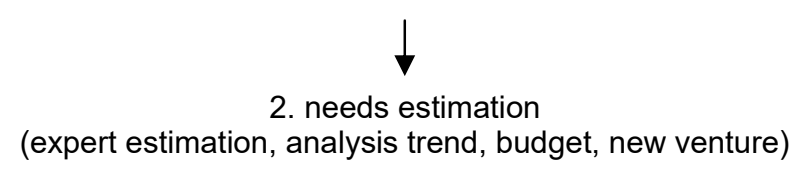

3. needs determination

(staffing lable)

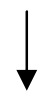

4. availabity analysis

(replacement chart, succesion planning, markover analysis, vacancy analysis
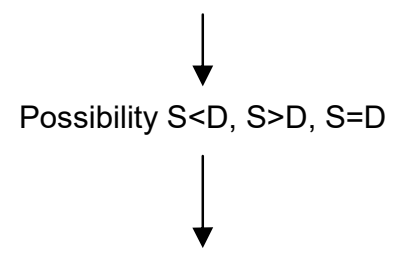

5. Program implementation

(withdrawal, training, work change behaviour, retiremet, dll

Figure 1 - Human resource planning model (Source: Hariandja, 2007) 
Another opinion was conveyed by Hasibuan SP in Mulyadi, et al (2012) regarding the stages of human resources planning, namely:

Procurement. Procurement must be planned properly and correctly so that the quality and quantity of human resources are in accordance with the needs of the company, including: withdrawal; selection.

Development. Development is the process of improving the technical skills, theoretical, conceptual and moral of employees the human resources through education and training. Education and training must be in accordance with the needs of current and future workers, including: education; training; mutation.

Compensation. Compensation is the provision of fringe benefits (direct) and indirect (indirect), money or goods to employees as compensation for services provided by the company. The principle of compensation is fair and decent. Fairly interpreted in accordance with its work performance, it is reasonable to be interpreted as being able to fulfill its primary needs and guided by the government's minimum wage limits and based on internal and external consistency.

Maintenance. Maintenance is an activity to maintain or improve the physical, mental and loyalty conditions of employees, so that they remain willing to work together until retirement. Maintenance needs to be planned properly so that labor turnover is relatively low, by providing welfare programs.

Discipline. Deployment is the most important human resources function and the key to the realization of goals because without good discipline, it is difficult to achieve maximum goals. Discipline is the desire and awareness to obey company regulations and social norms. The discipline is a reflection of the responsibilities of employees that must be carried out as well as possible rules of law sanctions.

Stop. Termination is the breaking of one's work relationship from the company. Termination must be planned as well as possible so as not to cause difficulties for the company, because sooner or later employees will stop for various reasons. Among them: retirement, fired.

The six concepts in above, we can see that human resources planning is important for the progress of a company therefore, the rate of interest (urgency) resources planning is quite high. The urgency of human resources planning consists of integrated plans for the future of the company including work design, recruitment, training, development, career management, succession, remuneration, separation and resignation, reward systems, and performance management. An integrated approach is not only important for good human resources practice, but also to ensure that company goals, structures and culture are effective and efficient.

Strategy of human resources Training and Development in the Industry Union. To improve the quality and competitiveness of the company, management needs to decide the human factor. This can be done by building basic mentality human resources, so that the growing awareness of quality in all levels of employees from top management to lower level employees. Mental base is a mental attitude that underlies the way of thinking how to behave and how to act in carrying out their daily work in harmony with the values of the company (Budi Santosa, 2004 in Soetjipto, 2008, p. 94). For development basic mentality for the realization of a work culture, the role of human resources needs to be optimized. Basic mental development can be done by human resources through employee training and development programs. This is as expressed by Pheter Sheal (2003) in Soetjipto (2008, p. 96) that there are 4 main reasons why employee training and development programs become increasingly important, they are: rapid changes in technology as well as people tasks; lack of direct skills and long-term skills; changes in the expectations and composition of the workforce; market competencies and pressures for improvement in the quality of products and services.

Given that the program of education and training is basically organized as a means to eliminate or at least reduce the gap between the competencies that exist today with the competence standard or expected to be done by someone, then in this case the training 
needs analysis and the development of a tool to identify gaps and analyze whether these gaps can be reduced or eliminated human resources through a training and development program.As expressed by Soetjipto $(2008$, p. 103$)$ that without a genuine needs analysis, it can be ascertained that the training program that is designed will only be successful in the classroom or training venue. This means that the implementation of training may work very well, but when participants (trainees) return to their respective workplaces, they become ignorant or confused about how to apply what they have learned from the training.

Competency-based human resources Development. Soetjipto (2008) argues that in company, human resources (labor) are a very important component, because the success of company depends on the quality of the people inside it. Changes in technology and environments move so fast in all joints of life that make competition so sharp. Therefore, the company must have a competent workforce so that it can respond quickly to any changes that exist, analyze the impact on the company, and prepare step accurate to deal with various conditions.

Individual performance in every activity is the key to achieving productivity, because performance is a result, where people and other resources in the company are together bring the final results based on the level of quality and standards that have been set. Consequently, company needs human resources who have expertise and unique abilities in accordance with the vision and mission of the company. Therefore, company must be able to develop the potential of human resources to be more creative and innovative. Competencybased human resources development is carried out in order to provide results that are in accordance with the goals and objectives of the company with predetermined performance standards, so that the company's target to provide excellent service to consumers will be achieved (Soetjipto, 2008).

Competencies Needed for the Future. Based on the ideas of the experts can be identified several main points about the quality that needs to be owned by someone at the executive, manager and employee level. Therefore, it is necessary to prepare the competencies needed to meet the new challenges in the future according to Spencer \& Spencer (1993, pp. 343-345), it is including the following.

Executive Level. At the executive level compensation is needed in the "strategic thinking" field, "change leadership", and "relationship management". The explanation of the human resources competencies is as follows:

- Competence "strategic thingking" is the competency to understand the trends of rapid environmental change, look at the market opportunities, thuman resourceseats, strengths and weaknesses of the company in order to identify "strategic response" optimally;

- Competence "change leadership" is the competency to communicate the vision and strategy of change that can be transformed to employees. Understanding of the company's vision by employees will lead to motivation and commitment so that employees can act as sponsors of innovation and "entrepreneurship", especially in allocating the best possible companyal resources to lead to the change process;

- Competence "relationship management" is the ability to improve relationships and network with others. Collaboration with other parties is needed for the success of the company.

Manager Level. At the manager level, at least competency aspects such as "flexibility", "interpersonal understanding" are needed, "Empowerment", "Team facilitation", and "portability". The explanation of the five competencies is as follows.

- Competence "flexibility" is the ability to change the structure and managerial systems if necessary companyal change strategy for the effective implementation of companyal tasks;

- Competence "interpersonal understanding" is the ability to understand the value of different types of people;

- " Empowerment " competence is capable of various information, conveying ideas by subordinates, developing employee development, delegating responsibilities, giving 
feedback suggestions, expressing positive expectations for subordinates and rewarding employees who have the motivation and responsibility greater than;

- Competence "facilitation team" is the ability to bring people to work together effectively to achieve common goals, including in this case is to give every person to participate and resolve conflicts;

- Competence "portability" is the ability to adapt and function effectively with overseas environment so managers should be 'portable'to the positions that exist in any country.

Employee Level. At the employee level required quality competencies such as "flexibility", "information search, motivation, and learning ability", "achievement motivation," work motivation under time pressure", "collaboration", and "service orientation to customers". The explanation of the six competencies is as follows.

- Competence "flexibility" is the ability to see change as an exciting opportunity rather than as a thuman resourceseat;

- The competence of "information search, motivation, and learning ability" is a competence about enthusiasm to seek learning opportunities about technical and interpersonal skills;

- "Achievement motivation" competence is the ability to drive innovation, continuous improvement in quality and productivity needed to meet competency challenges;

- The competence of "work motivation under time pressure" is a combination of flexibility, achievement motivation, stress resistance, and companyal commitment that makes individuals work well under the demand for new products, even in limited time;

- "Collaboration" competence is the ability to work cooperatively in multi-disciplinary groups, put positive expectations on others, interpersonal understanding, and companyal commitment;

- "Service to customer orientation" competence is a great desire to serve customers well, and initiatives to overcome obstacles in the company in order to overcome the problems faced by customers.

\section{CONCLUSION}

Based on the finding and discussion above, it can be concluded that company need human resources who have expertise and unique abilities in accordance with the vision and mission of the company. Therefore company must be able to develop the potential of human resources to be more creative and innovative. Competency based human resources development is carried out in order to provide results in accordance with the goals and objectives of the company with the performance standards that have been set, executives needed compensation in the field of strategic thinking, Change leadership, and relationship management. At the manager level, at least competency aspects such as flexibility, interpersonal understandings are needed such as empowerment, team facilitation, and portability. At the employee level required quality competencies such as flexibility, information search, motivation, and learning ability, achievement motivation, work motivation under time pressure, collaboration, and service orientation to customers. Those are the classification of strategy in developing human resources management planning. This study result imply to improve business sector especially in manage human resources.

\section{REFERENCES}

1. Hariandja, Marihot Tua Efendi. (2007). Manajemen Sumber Daya Manusia: pengadaan, pengembangan, pengkompensasian, dan peningkatan produktifitas kerja pegawai. Jakarta. PT. Gramedia Widiasarana Indonesia.

2. Dörnyei, Zoltán. 2007. Research Methods in Applied Linguistics. New York: Oxford University Press. 
3. Johnson et al. 2007. Educational Research: Quantitative, Qualitative, and Mixed Approaches. New York: Sage Publication.

4. Mulyadi, Dedi, Sonny Hersona GW, Cheppi Rangga Casmita. (2012). Analisis Perencanaan Sumber Daya Manusia Terhadap Penempatan Tenaga Struktural Pada Kantor.

5. Kementerian Agama Kabupaten Karawang. E-Jurnal: BPFE Unsika 1 (1), 12-19.

6. Sobakh. (2017). Efforts To Improve Teacher Quality. E-journal: IOSR Journal of Research \& Method in Education (IOSR-JRME) 7 (3), 67-71.

7. Sobakh. (2017) Professional Teachers' Perspective toward an Effective Teaching Technique: A Case Study International Journal of Learning and Development. E-journal: International Journal of Learning and Developmen, 7 (4), 53-59.

8. Prashanti, K. (2013). Human Resource Planning - An Analytical Study. Vol II. 2013. International Journal of Business Management and Invention. India.

9. Soetjiptono, Budi W. (2008). Kisah Sukses Para Kampiun SDM. Jakarta: Salemba Empat

10. Sofo, Francesco. Human Resources and Their Development; Human Resources Development plans. Ecyclopedia of Life Support Systems. Vol 1. Australia.

11. Spencer,M.Lyle and Spencer,M.Signe. (1993). Competence at Work:Models for Superrior Performance, John Wily \& Son,Inc,New York, USA.

12. Veithzal Rivai. (2004). Manajemen Sumber Daya Manusia Untuk Perusahaan : Dari Teori Ke Praktik. PT. Raja Grafindo Persada, Jakarta.

13. Widajanti, Erni. (2007). Perencanaan Sumberdaya Manusia yang Efektif: Strategi Mencapai Keunggulan Kompetitif. E-Jurnal: Jurnal Ekonomi dan Kewirausahaan 7 (2), 105-114. 